\title{
Real-time Visualization of Oxygen Partial Pressures in Straight Channels of Running Polymer Electrolyte Fuel Cell with Water Plugging
}

Katsuya Nagase,${ }^{a, b}$ Takeo Suga,${ }^{c}$ Yuzo Nagumo, ${ }^{d}$ Makoto Uchida,${ }^{e}$ Junji Inukai,,${ }^{e *}$ Hiroyuki Nishide ${ }^{c, * *}$ and Masahiro Watanabe $e^{e, * *}$

${ }^{a}$ Interdisciplinary Graduate School of Medicine and Engineering, University of Yamanashi, 4-4-37 Takeda, Kofu, Yamanashi 400-8510, Japan

${ }^{b}$ TAKAHATA PRECISION JAPAN CO., LTD., 390 Maemada, Sakaigawa-cho, Fuefuki, Yamanashi 406-0843, Japan

${ }^{c}$ Department of Applied Chemistry, Waseda University, 3-4-1 Okubo, Shinjuku, Tokyo 169-8555, Japan.

${ }^{d}$ Shimadzu Corporation, 3-9-4 Hikaridai, Seika-cho, Kyoto 619-0237, Japan

${ }^{e}$ Fuel Cell Nanomaterials Center, University of Yamanashi, 6-43 Miyamae-cho, Kofu, Yamanashi 400-8511, Japan.

\begin{abstract}
Visualization inside polymer electrolyte fuel cells (PEFCs) for elucidating the reaction distributions is expected to improve the performance, durability, and stability. An oxygen-sensitive film of a luminescent porphyrin was used to visualize the oxygen partial pressures in five straight gas-flow channels of a running PEFC with liquid-water blockages formed at the end of the channels. The blockage greatly lowered and unstabilized the cell voltage. The oxygen partial pressure decreased nearly to $0 \mathrm{kPa}$ in the blocked channel. With a water
\end{abstract}


blockage in a channel, the oxygen partial pressures in the adjacent channels were lowered due to an extra demand of oxygen consumption. When the number of the blocked channels increased, the oxygen partial pressure in the unblocked channels became much lowered. When the water blockages disappeared, the oxygen partial pressures quickly returned to the values before plugging. The influence of the cross flows of air through the gas diffusion layers in straight channels was much smaller than that in serpentine flow channels.

Keywords: Polymer electrolyte fuel cell; Oxygen partial pressure; Gas-flow channel; Gas diffusion layer; Water blockage; Cross flow

* Corresponding author. Tel.: +81 55254 7129; fax: +81 552547129.

E-mail address: jinukai@yamanashi.ac.jp (J. Inukai).

** Corresponding author. Tel.: +81 33200 2669; fax: +81 332095522.

E-mail address: nishide@waseda.jp (H. Nishide).

*** Corresponding author. Tel.: +81 55254 7091; fax: +81 552547091. E-mail address:m-watanabe@yamanashi.ac.jp (M. Watanabe). 


\section{Introduction}

Polymer electrolyte fuel cells (PEFCs) produce electricity directly from hydrogen and oxygen and are expected as a new clean source of energy with their high efficiency and low emission. For commercialization of PEFCs, higher performance, lower cost, and higher durability are still required. The water management is one of the most important issues for PEFCs, because the accumulation of water could flood the porous electrodes and gas-flow channels to deteriorate performance [1,2], whereas insufficiency in the proton conductivity and degradation of membranes could occur as a result of membrane drying out [3-5]. The generation and the distribution of liquid water inside the fuel cells has been actively studied and successfully visualized by direct optical observation [6-11], neutron radiography imaging [12-19], X-ray imaging [20-23], and magnetic resonance imaging [24-26]. The oxygen partial pressure $\left(\mathrm{p}_{\mathrm{O} 2}\right)$ is also an essential factor, which is influenced by the consumption of oxygen for the power generation [27-29], the existence of the cross flows through the gas diffusion layer (GDL) [2,30], and the production of gaseous and liquid water [10,29,31,32]. In order to understand the distribution of $p_{\mathrm{O} 2}$, we have developed a nondestructive, real-time/space visualization system for $p_{02}$ in operating fuel cells $[10,27-29,33]$. In our previous paper, we visualized $p_{\mathrm{O} 2}$ and water blockages simultaneously in a triple-serpentine PEFC to investigate the relationship between the two [10]. $p_{02}$ in a serpentine gas-flow channel around water blockages decreased nearly to $0 \mathrm{kPa}$, but along the channel from the entrance to the plugging position, $p_{\mathrm{O} 2}$ was considerably large, which suggested the transfer of air through the GDL from the other serpentine channels. In this paper, we visualized $p_{\mathrm{O} 2}$ in five straight flow channels of an operating PEFC with/without water 
blockages. Very differently from the triple-serpentine channels, the effects of the side flows through the GDL from the neighboring channels were very small in a PEFC with five straight channels.

\section{Experimental}

For the gas diffusion electrodes (GDEs), a paste of Pt catalyst supported on carbon black (TEC10E50, 46.4 wt\%-Pt, Tanaka Kikinzoku Kogyo K.K.) containing Nafion ionomers (ion exchange capacity (IEC) $=0.9$ mequiv $\mathrm{g}^{-1}$, DE521, E.I. Du Pont de Nemours \& Co., Inc.) as a binder, with a Nafion mass (dry basis) to carbon black ratio adjusted to 0.7 , was uniformly coated on a GDL, 25BCH (SGL Technologies, GmbH), by use of a pulse-swirl-spray apparatus (PSS, Nordson Co., Ltd.), and then dried at $60{ }^{\circ} \mathrm{C}$. The Pt loading was $0.5 \pm 0.1 \mathrm{mg} \mathrm{cm}^{-2}$ both at the anode and the cathode. An MEA was prepared by hot pressing a membrane, NRE212 (E.I. Du Pont de Nemours \& Co., Inc.), with the GDEs at $140{ }^{\circ} \mathrm{C}$ and $1.0 \mathrm{MPa}$ for $3 \mathrm{~min}$. Fig. 1(a) shows the schematic representation of the gas-flow channels of the cathode and the anode, and Fig. 1(b) the five gas-flow channels (54 mm in length, assigned as Channels 1-5) and the MEA. The channel depth and width of the cell were 0.6 and $1 \mathrm{~mm}$, respectively. The length of the catalyst layer was $50 \mathrm{~mm}$, thus the areas of the first $2 \mathrm{~mm}(0-2 \mathrm{~mm}$ along the channel length) and the last $2 \mathrm{~mm}(52-54 \mathrm{~mm}$ along the channel length) of the channels had no catalysts in the MEA. Gas manifolds were placed at the inlet and outlet of the channels. The exit of the channel was exposed to the atmosphere. Instrumental setups for visualization have been reported in detail elsewhere [27,29]. A cell with a cathode endplate made of transparent quartz was used in the present experiments. A dye 
film ([tetrakis (pentafluorophenyl) porphyrinato] platinum + poly(1-trimethylsilyl-1-propyne)) [33] was coated on the GDL surface [29] at the cathode as an oxygen sensor to visualize $p_{\mathrm{O} 2}$ on the GDL surface. In a separate experiment, the same dye film was coated on the upper-channel wall of the PEFC (but not on the GDL) for detecting $p_{02}$ on the upper-channel wall. Laser light (407 nm) was diffused and frontally irradiated onto the transparent cell window. The emission from the cell was filtered $(>610 \mathrm{~nm})$, and images were captured with a CCD camera. Calibration curves were obtained before the cell operation by changing $p_{\mathrm{O} 2}$ inside the cell. By use of the calibration curves, the emission signals from the cell were converted to $p_{02}$. The spatial resolution was $120 \mu \mathrm{m}$. Images were captured every $1.5 \mathrm{~s}$ during the cell operation. Water droplets were simultaneously observed with $p_{\mathrm{O} 2}$ using this optical system $[10,11]$. The location of the water droplets were also confirmed by looking directly with eyes through the endplate. The cell temperature was set at $80^{\circ} \mathrm{C}$, and gases were humidified at $80 \%$ and $90 \% \mathrm{RH}$. The hydrogen was supplied at $0.2 \mathrm{dm}^{3} \mathrm{~min}^{-1}$ to the anode gas-flow. The overall oxygen utilization (Uo2) was set at $0,15,30,45,60$, and $75 \%$ at a current density of $0.6 \mathrm{~A} \mathrm{~cm}^{-2}$ by controlling the air flow to the cathode gas-flow channels.

\section{Results and discussion}

Fig. 2 shows $p_{02}$ on the GDL surface inside the five straight gas-flow channels at $80 \% \mathrm{RH}$. At the open circuit voltage with no power generation, po2 was $13 \mathrm{kPa}$ in all channels (Fig. 2(a)). The pressure loss was very small compared with that in serpentine channels [29,34]. Fig. 2(b) was obtained 5 minutes after the current 


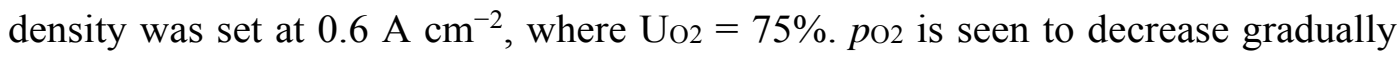
along the channels from the inlet to the outlet. In the three central channels (Channels 2, 3, and 4), $p_{\mathrm{O} 2}$ decreased in a similar manner. In Channels 1 and 5, $p_{\mathrm{O} 2}$ was higher than that in other channels at the same channel length. The difference among the channels can be explained by the geometry of the cathodic reaction area. No water droplets were observed at $80 \% \mathrm{RH}$ and $\mathrm{U}_{\mathrm{O} 2}=75 \%$.

Fig. 3 shows $p_{\mathrm{O} 2}$ on the GDL at 90\% RH. At Uo2 $=0 \%$ (Fig. 3(a)), $p_{\mathrm{O} 2}$ was 12 $\mathrm{kPa}$ throughout the channels. At $\mathrm{U}_{\mathrm{O} 2}=15 \%$ (Fig. 3(b)), $p_{\mathrm{O} 2}$ was steadily observed to decrease along the channels from the inlet to the outlet at the cell voltage of 0.50 V. As Uo2 was increased to $30 \%$, the cell voltage became $0.46 \mathrm{~V}$ but abruptly dropped to $0.38 \mathrm{~V}$. After minutes, the voltage suddenly increased to $0.51 \mathrm{~V}$, higher by $0.05 \mathrm{~V}$ than that before the voltage drop, which will be later discussed. The two stages of voltage at 0.51 and $0.38 \mathrm{~V}$ periodically repeated approximately every two minutes. This voltage change was separately observed in a cell with carbon endplates with the same design of flow channels (Fig. 1(a)), therefore, this phenomenon is not unique to our see-through cell. Figs. 3(c) and 3(d) show $p_{\mathrm{O} 2}$ at a voltage drop and a recovery, respectively. At the cell voltage drop, Channel 3 is seen blue except near the inlet. This means that $p_{\mathrm{O} 2}$ on the GDL decreased nearly to $0 \mathrm{kPa}$ in Channel 3. Through the transparent endplate, very small water droplets were observed on the rib walls near the outlet to coalesce themselves to be a blockage close to the outlet at the voltage drop. The water blockages were observed only near the outlets. When the water blockage was blown out from the channel, the voltage recovered. Therefore, water blockages near the outlet hindered an air flow through the channel, so that $p_{\mathrm{O} 2}$ on the GDL in the channel, except only near the 
inlet, became nearly $0 \mathrm{kPa}$. The blocked channel was not only Channel 3 , but different channels were also observed to be plugged. Two channels were sometimes observed to be blocked, too, which will be later shown. Independently, we visualized $p_{02}$ on the upper-channel wall with the dye film on the channel wall. Fig. 4 shows $p_{02}$ on the upper-channel wall, which also became $0 \mathrm{kPa}$ except near the inlet when Channel 4 was blocked. Therefore, $p_{\mathrm{O} 2}$ in the whole flow channel, from the upper-channel wall to the GDL, was confirmed to be $0 \mathrm{kPa}$, when the channel was blocked. Figs. 5(a) and 5(b) show $p_{\mathrm{O} 2}$ along Channels 3 and 4, respectively, at $\mathrm{U}_{02}=0 \%$ (blue line), $15 \%$ (red line), 30\% without a water blockage (purple line), and $30 \%$ with a blockage in Channel 3 (green line). During the power generation $\left(\mathrm{U}_{\mathrm{O} 2}=15 \%\right.$ and $\left.30 \%\right)$, there appeared small fluctuations on the $p_{\mathrm{O} 2}$ curves (Fig. 5). This fluctuation was because of the water mists on the wall of the transparent upper flow channel at a high humidity, which scatter the irradiation and emission lights $[10,35]$. In the channels without a water blockage, $p_{\mathrm{O} 2}$ appeared to decrease smoothly, indicating a homogeneous consumption of oxygen along the channel length. Interestingly, near the inlet between 0 and $2 \mathrm{~mm}$ along the channel length with no catalyst layer (Fig. 1(b)), $p_{\mathrm{O} 2}$ is already seen to decrease by the oxygen consumption at the catalyst-coated region $(2-52 \mathrm{~mm})$. Approximately at $50 \mathrm{~mm}$ along the channel length, $p_{\mathrm{O} 2}$ begins to increase because of no catalyst layer between 52 and $54 \mathrm{~mm}$. When there was a water blockage in Channel 3, po2 steeply decreased near the inlet in the channel and became nearly $0 \mathrm{kPa}$ in the area from 8 $\mathrm{mm}$ to the outlet (green line in Fig. 5(a)). Fig. 5(b) shows $p_{\mathrm{O} 2}$ in Channel 4, an adjacent channel to the blocked channel. With no blockage, the $p_{\mathrm{O} 2}$ distributions were similar in Channels 3 and 4 . When a blockage existed in Channel 3 at Uo2 $=$ 
$30 \%, p_{\mathrm{O} 2}$ in Channel 4 decreased by approximately $1 \mathrm{kPa}$ except at the inlet and the outlet. The decrease in $p_{\mathrm{O} 2}$ in the adjacent channel should be attributed to a larger consumption of oxygen instead of the blocked, dead channel to keep the total power generation constant. The sudden decrease of the voltage with emerging a blockage can be explained by the increase in current density except on the blocked flow field, or the sudden decrease in the active area for the power generation. During the power generation with a blocked channel, the rate of the water generated at the active area increased because of the higher local current density. The increase in water production should have increased the proton conductivity of the catalyst layer and membrane, which could be the reason for the increase in the voltage from 0.46 to $0.51 \mathrm{~V}$ after the first plugging. A slight increase in voltage has also been reported after a temporary increase in current density of a PEFC [5]. The decrease in $p_{02}$ in the channel adjacent to the blocked channel was very different from the results observed in serpentine channels [10], where a large cross flow $[2,30]$ between the channels through the GDL effectively supplied oxygen to the blocked channel to make the power generation possible. In the adjacent serpentine channels, the decrease in $p_{\mathrm{O} 2}$ was visualized to be negligibly small [10]. When a blockage disappeared in the straight channels, $p_{\mathrm{O} 2}$ as well as the voltage quickly returned to the value before the formation of the blockage. This sudden recovery was also not the case in a PEFC with serpentine channels; in a serpentine channel after a disappearance of a blockage, a low power generation continued for minutes in the channel because of liquid water having formed and accumulated in the catalyst layer [10]. Wetting of the catalyst layer under the blocked straight flow channel, therefore, should be very low, because of no water production with the loss of 
oxygen supply. It has been reported that the PEFC with straight channels has a low tolerance for flooding by the formation of liquid water $[2,8,36]$. According to the present visualization results, PEFCs with straight channels are more "sensitive" to liquid water than those with serpentine channels; the cell voltage easily drops but easily recovers. Alternatively, since the influence of the cross flows through the GDL across the channels is smaller for straight channels than for serpentine channels, the water evacuation under the ribs is expected to be smaller in a PEFC with straight channels. Therefore, in a PEFC with straight channels, although the catalyst layer under the flow channels might not be wet, the catalyst layer as well as the GDL under the ribs could be very wet.

When Uo2 was increased from $30 \%$ to $35 \%$, the cell voltage showed a larger instability; the voltage drop $(0.17 \mathrm{~V})$ and recovery $(0.46 \mathrm{~V})$ were periodically repeated approximately every five seconds. Fig. 6 shows the visualization images during the voltage drop. Not only one but two channels (Channels 3 and 5) were blocked at $\mathrm{U}_{\mathrm{O} 2}=35 \%$. The blockage disappeared and appeared very quickly in one second. Fig. 7(a) shows the visualization images from left to right, when water blockages existed in Channel 5, in Channel 3, and both in Channels 3 and 5. In Fig. 7(b), $p_{\mathrm{O} 2}$ along Channel 4 sandwiched by Channels 3 and 5 is plotted. When there was one blockage in Channel 5 (red line) or Channel 3 (green line), por in Channel 4 was nearly the same and the voltage was $0.46 \mathrm{~V}$. When there was two blockages in Channels 3 and 5 (blue line), $p_{\mathrm{O} 2}$ in Channel 4 became lowered and the voltage dropped to $0.17 \mathrm{~V}$ for the compensation of the inactive Channels 3 and 5 . The multiple water blockages much unstabilized the voltage accompanied by the continuous change of the plugged channels. 


\section{Conclusions}

$p_{\mathrm{O} 2}$ in a PEFC with five straight channels was visualized, when one or two channels were blocked with liquid water near the outlet. $p_{\mathrm{O} 2}$ in the blocked channels became nearly $0 \mathrm{kPa}$, where the power generation was not possible. p $p_{\mathrm{O} 2}$ in the adjacent active channels became lower because of the larger power generation. When there were multiple blockages, the alteration of the blockages proceeded very fast in one second. When blockages disappeared, $p_{\mathrm{O} 2}$ and the voltage quickly returned to the values without blockages. These results were very different from those in serpentine channels, mainly because of the small cross flows, because the cross flow through the GDL of the straight channels was smaller than that of the serpentine channels. The present results should be reflected for the improvement of designs of channels and MEAs.

\section{Acknowledgements}

This study was supported by the New Energy and Industrial Technology Development Organization (NEDO) and Japan Science and Technology Agency (JST), Japan. 
References

[1] U. Pasaogullari, C.Y. Wang, J. Electrochem. Soc. 151 (2004) A399-A406.

[2] H. Li, Y. Tang, Z. Wang, Z. Shi, S. Wu, D. Songa, J. Zhang, K. Fatih, J. Zhang, H. Wang, Z. Liu, R. Abouatallah, A. Mazza, J. Power Sources 178 (2008) 103-117.

[3] M. Cappadonia, J.W. Erning, S.M.S. Niaki, U. Stimming, Solid State Ionics 77 (1995) 65-69.

[4] J.R. Atkins, S.C. Savett, S.E. Creager, J. Power Sources 128 (2004) 201-207.

[5] H. Yu, C. Ziegler, J. Electrochem. Soc. 153 (2006) A570-A575.

[6] K. Tüber, D. Pócza, C. Hebling, J. Power Sources 124 (2003) 403-414.

[7] K. Sugiura, M. Nakata, T. Yodo, Y. Nishiguchi, M. Yamauchi, Y. Itoh, J. Power Sources 145 (2005) 526-533.

[8] X. Liu, H. Guoa, C. Ma, J. Power Sources 156 (2006) 267-280.

[9] I.S. Hussaini, C.Y. Wang, J. Power Sources 187 (2009) 444-451.

[10] K. Takada, Y. Ishigami, J. Inukai, Y. Nagumo, H. Takano, H. Nishide, and M. Watanabe, J. Power Sources 196 (2011) 2635-2639.

[11] K. Takada, Y. Ishigami, S. Hirakata, M. Uchida, Y. Nagumo, J. Inukai, H. Nishide, M. Watanabe, Electrochemistry 79 (2011) 388-391.

[12] M.A. Hickner, N.P. Siegel, K.S. Chen, D.N. McBrayer, D.S. Hussey, D.L. Jacobson, M. Arif, J. Electrochem. Soc. 153 (2006) A902-A908.

[13] Y.-S. Chen, H. Peng, D.S. Hussey, D.L. Jacobson, D.T. Tran, T. Abdel-Baset, M. Biernacki, J. Power Sources 170 (2007) 376-386.

[14] A. Turhan, K. Heller, J.S. Brenizer, M.M. Mench, J. Power Sources 180 (2008) $773-783$.

[15] A.Z. Weber, M.A. Hickner, Electrochim. Acta 53 (2008) 7668-7674.

[16] M.A. Hickner, N.P. Siegel, K.S. Chen, D.S. Hussey, D.L. Jacobson, M. Arif, J. Electrochem. Soc. 155 (2008) B294-B302.

[17] H. Murakawa, T. Ueda, T. Yoshida, K. Sugimoto, H. Asano, N. Takenaka, K. Mochiki, H. Iikura, R. Yasuda, M. Matsubayashi, Nucl. Instr. and Meth. A 605 (2009) 127-130.

[18] H. Markötter, I. Manke, R. Kuhn, T. Arlt, N. Kardjilov, M.P. Hentschel, A. Kupsch, A. Lange, C. Hartnig, J. Scholta, J. Banhart, J. Power Sources 219 (2012) 120-125.

[19] P. Oberholzer, P. Boillat, A. Kaestner, E.H. Lehmann, G.G. Scherer, T.J. Schmidt, A. Wokaun, J. Electrochem. Soc. 160 (2013) F659-F669. 
[20] P.K. Sinha, P.P. Mukherjee, C.-Y. Wang, J. Mater. Chem. 17 (2007) 3089-3103.

[21] S.J. Lee, N.-Y. Lim, S. Kim, G.-G. Park, C.-S. Kim, J. Power Sources 185

(2008) 867-870.

[22] P. Deevanhxay, T. Sasabe, S. Tsushima, S. Hirai, Electrochem. Commun. 22 (2012) 33-36.

[23] J. Lee, J. Hinebaugh, A. Bazylak, J. Power Sources 227 (2013) 123-130.

NMR (MRI)

[24] S. Tsushima, K. Teranishi, S. Hirai, Electrochem. Solid-state Lett. 7 (2004) A269-A272.

[25] K.W. Feindel, S.H. Bergens, R.E. Wasylishen, Phys. Chem. Chem. Phys. 9 (2007) 1850-1857.

[26] S. Tsushima, T. Nanjo, S. Hirai, ECS Trans. 11 (2007) 435-443.

[27] J. Inukai, K. Miyatake, K. Takada, M. Watanabe, T. Hyakutake, H. Nishide, Y. Nagumo, M. Watanabe, M. Aoki, H. Takano, Angew. Chem. Int. Ed. 47 (2008) 2792-2795.

[28] Y. Ishigami, K. Takada, H. Yano, J. Inukai, M. Uchida, Y. Nagumo, T. Hyakutake, H. Nishide, M. Watanabe, J. Power Sources 196 (2011) 3003-3008.

[29] Y. Ishigami, W. Waskitoaji, M. Yoneda, K. Takada, T. Hyakutake, T. Suga, M. Uchida, Y. Nagumo, J. Inukai, H. Nishide, M. Watanabe, J. Power Sources, DOI: 10.1016/j.jpowsour.2014.07.017.

[30] J.P. Feser, A.K. Prasad, S.G. Advani, J. Power Sources 161 (2006) 404-412.

[31] C.Y. Wang, Chem. Rev., 104 (2004) 4727-4766.

[32] S. Hirakata, T. Mochizuki, M. Uchida, H. Uchida, M. Watanabe, Electrochimi. Acta 108 (2013) 304-312.

[33] T. Hyakutake, Y. Ishigami, J. Kato, J. Inukai, K. Miyatake, H. Nishide, M. Watanabe, Macromol. Chem. Phys. 212 (2011) 42-47.

[34] J. Wang, Energy Sci. Technol. 2 (2011) 1-12.

[35] J. Inukai, K. Miyatake, Y. Ishigami, M. Watanabe, T. Hyakutake, H. Nishide, Y. Nagumo, M. Watanabe, A. Tanaka, Chem. Commun 15 (2008) 1750-1752.

[36] T. Fabiana, R. O’Hayre, S. Litster, F.B. Prinza, J.G. Santiago, J. Power Sources 195 (2010) 3201-3206. 


\section{Figure captions}

Fig. 1. Schematic representations of gas-flow channels (a) and gas-flow field and MEA (b) with channel numbers, \#1 to 5 .

Fig. 2 p 2 on the GDL surface visualized in an operating PEFC. (a) $\mathrm{U}_{\mathrm{O} 2}=0 \%$, Air flow rate $=0.332 \mathrm{dm}^{3} \mathrm{~min}^{-1}$. (b) $\mathrm{U}_{02}=75 \%$, Air flow rate $=0.066 \mathrm{dm}^{3} \mathrm{~min}^{-1}$, current density $=0.6 \mathrm{~A} \mathrm{~cm}^{-2}$. Cell temperature $=80{ }^{\circ} \mathrm{C}$; relative humidity $=80 \% ; \mathrm{H}_{2}$ flow rate $=0.200$ $\mathrm{dm}^{3} \min ^{-1}$

Fig. 3 po2 on the GDL surface visualized in an operating PEFC. (a) $\mathrm{UO}_{\mathrm{O} 2}=0 \%$, Air flow rate $=0.332 \mathrm{dm}^{3} \min ^{-1}$. (b) $\mathrm{Uo}_{\mathrm{O} 2}=15 \%$, Air flow rate $=0.332 \mathrm{dm}^{3} \min ^{-1}$. (c) $\mathrm{Uo}_{\mathrm{O} 2}=30 \%$, Air flow rate $=0.166 \mathrm{dm}^{3} \mathrm{~min}^{-1}$. Water blockage existed at the end of Channel 3. (d) $\mathrm{Uo2}=30 \%$, Air flow rate $=0.166 \mathrm{dm}^{3} \mathrm{~min}^{-1}$. No water blockage. Cell temperature $=80$ ${ }^{\circ} \mathrm{C}$; relative humidity $=90 \% ; \mathrm{H}_{2}$ flow rate $=0.200 \mathrm{dm}^{3} \mathrm{~min}^{-1}$; current density $=0.6 \mathrm{~A}$ $\mathrm{cm}^{-2}$ except (a).

Fig. $4 p_{\mathrm{O} 2}$ on the surface of the upper flow channel visualized in an operating PEFC. $\mathrm{U}_{02}=30 \%$, Air flow rate $=0.166 \mathrm{dm}^{3} \mathrm{~min}^{-1}$. Water blockage existed at the end of Channel 4. Cell temperature $=80{ }^{\circ} \mathrm{C}$; relative humidity $=90 \% ; \mathrm{H}_{2}$ flow rate $=0.200$ $\mathrm{dm}^{3} \min ^{-1}$; current density $=0.6 \mathrm{~A} \mathrm{~cm}^{-2}$.

Fig. 5 p 2 along Channel 3 (a) and Channel 4 (b). $\mathrm{U}_{\mathrm{O} 2}=0,15,30 \%$. Data were obtained from Fig. 3. $\mathrm{U}_{\mathrm{O} 2}=0 \%$, blue line. $\mathrm{U}_{\mathrm{O} 2}=15 \%$, red line. $\mathrm{U}_{\mathrm{O} 2}=30 \%$ with no water blockage, purple line. $\mathrm{U}_{\mathrm{O} 2}=30 \%$ with a water blockage in Channel 3, green line. 
Fig. $6 p_{\mathrm{O} 2}$ on the GDL surface in an operating PEFC. Cell temperature $=80{ }^{\circ} \mathrm{C}$; relative humidity $=90 \% ; \mathrm{H}_{2}$ flow rate $=0.200 \mathrm{dm}^{3} \min ^{-1}$; Air flow rate $=0.142 \mathrm{dm}^{3} \mathrm{~min}^{-1}$; current density $=0.6 \mathrm{~A} \mathrm{~cm}^{-2} ; \mathrm{U}_{\mathrm{O} 2}=35 \%$. Each image was obtained in $1.5 \mathrm{~s}$.

Fig. 7 p 2 along Channel 4 with Channel 5 blocked (red line), Channel 3 blocked (green line), and Channels 3 and 5 blocked (blue line). Cell temperature $=80^{\circ} \mathrm{C}$; relative humidity $=90 \% ; \mathrm{H}_{2}$ flow rate $=0.200 \mathrm{dm}^{3} \mathrm{~min}^{-1}$; Air flow rate $=0.142 \mathrm{dm}^{3} \mathrm{~min}^{-1}$; current density $=0.6 \mathrm{~A} \mathrm{~cm}^{-2} ; \mathrm{Uo}_{2}=35 \%$. 
Figure 1

Nagase et al.

(a)

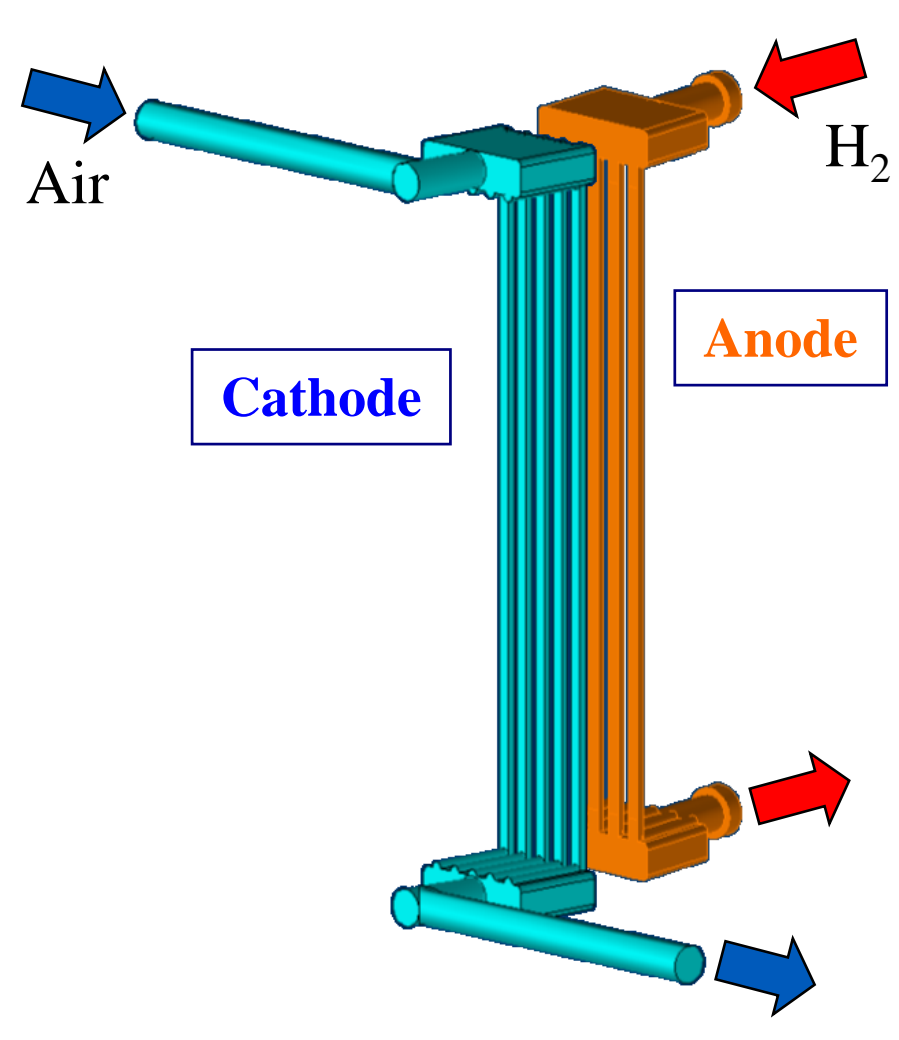

(b)

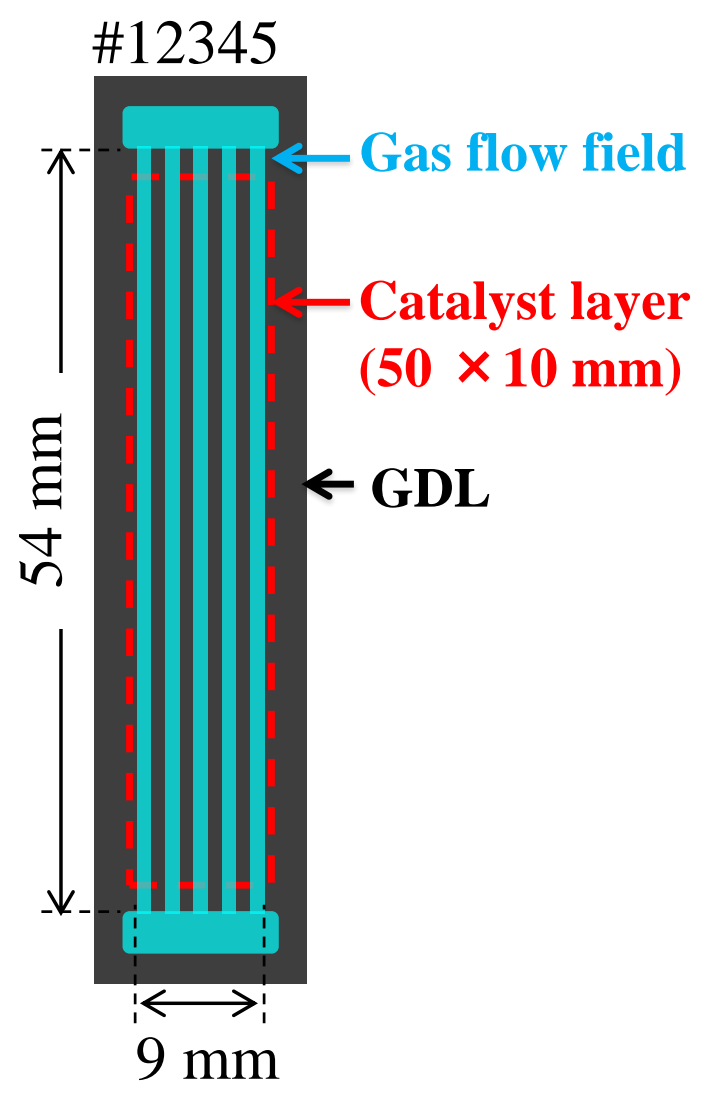


(a)

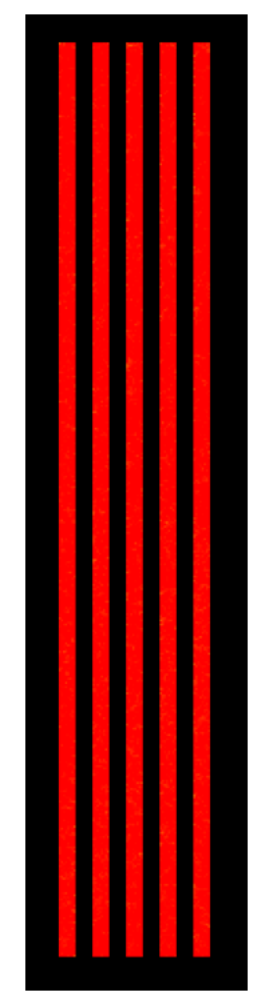

(b)

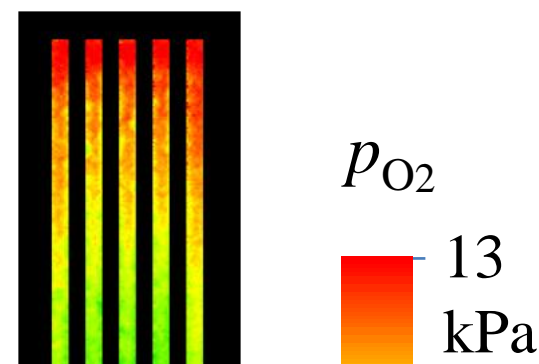

8

4

$\mathrm{kPa}$

$$
8
$$

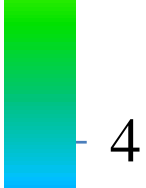

\section{Figure 2
Nagase et al. \\ Figure 2
Nagase et al.}

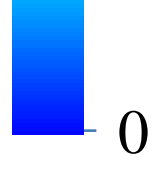




\section{Figure 3}

Nagase et al.

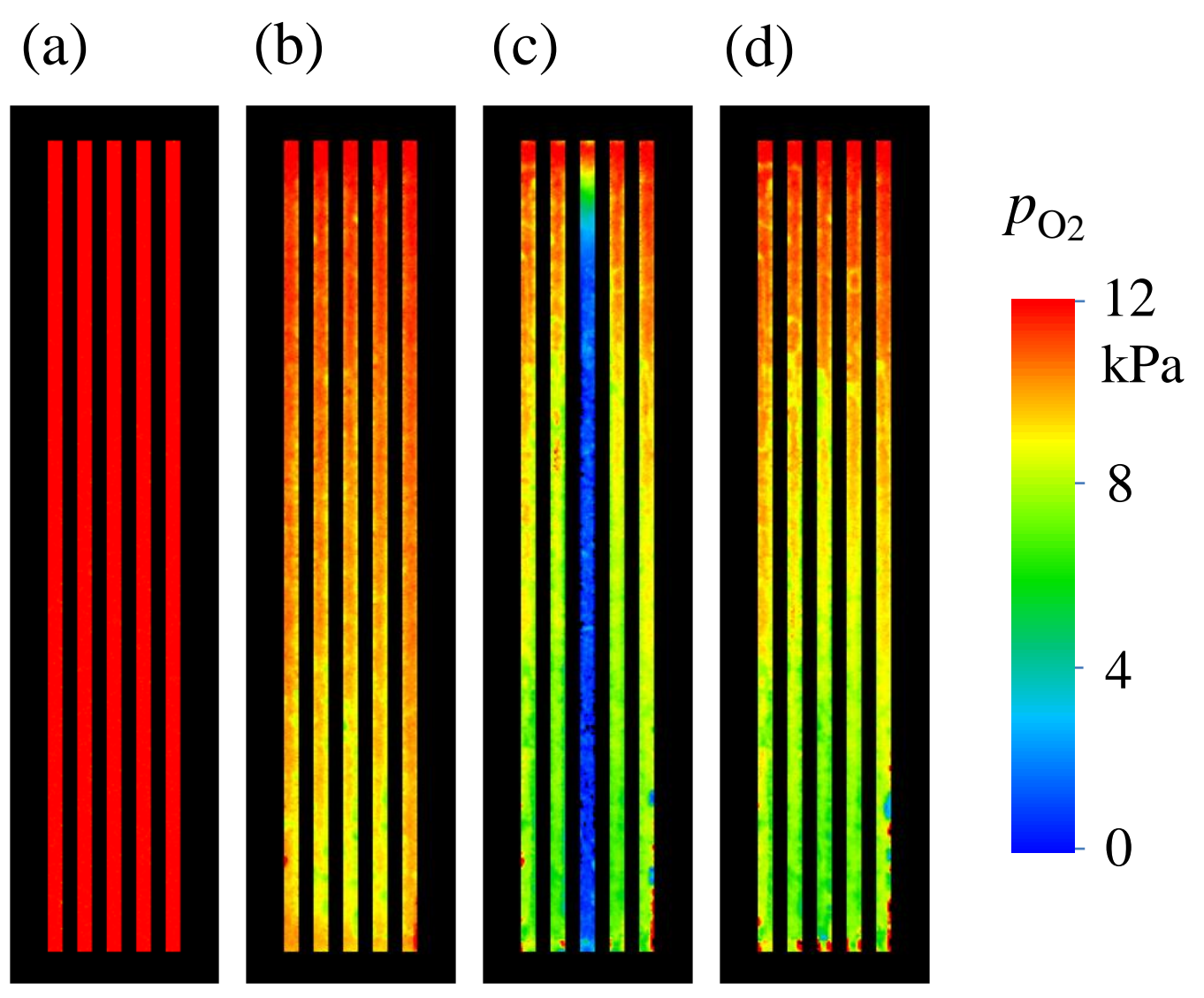


Figure 4

Nagase et al.

$p_{\mathrm{O} 2}$

12
$\mathrm{kPa}$

8

4

0 


\section{Figure 5}

Nagase et al.

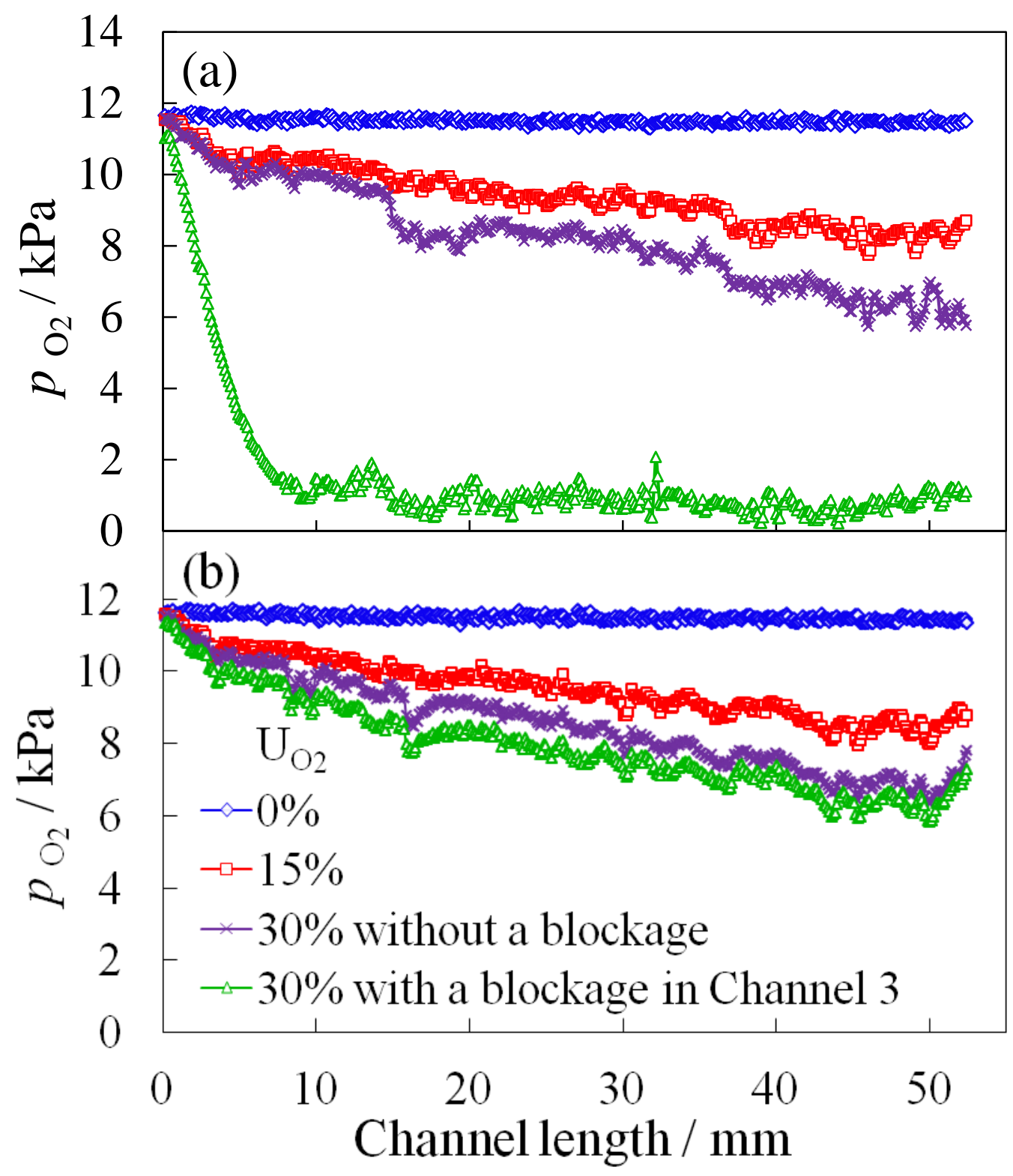




\section{Figure 6}

Nagase et al.

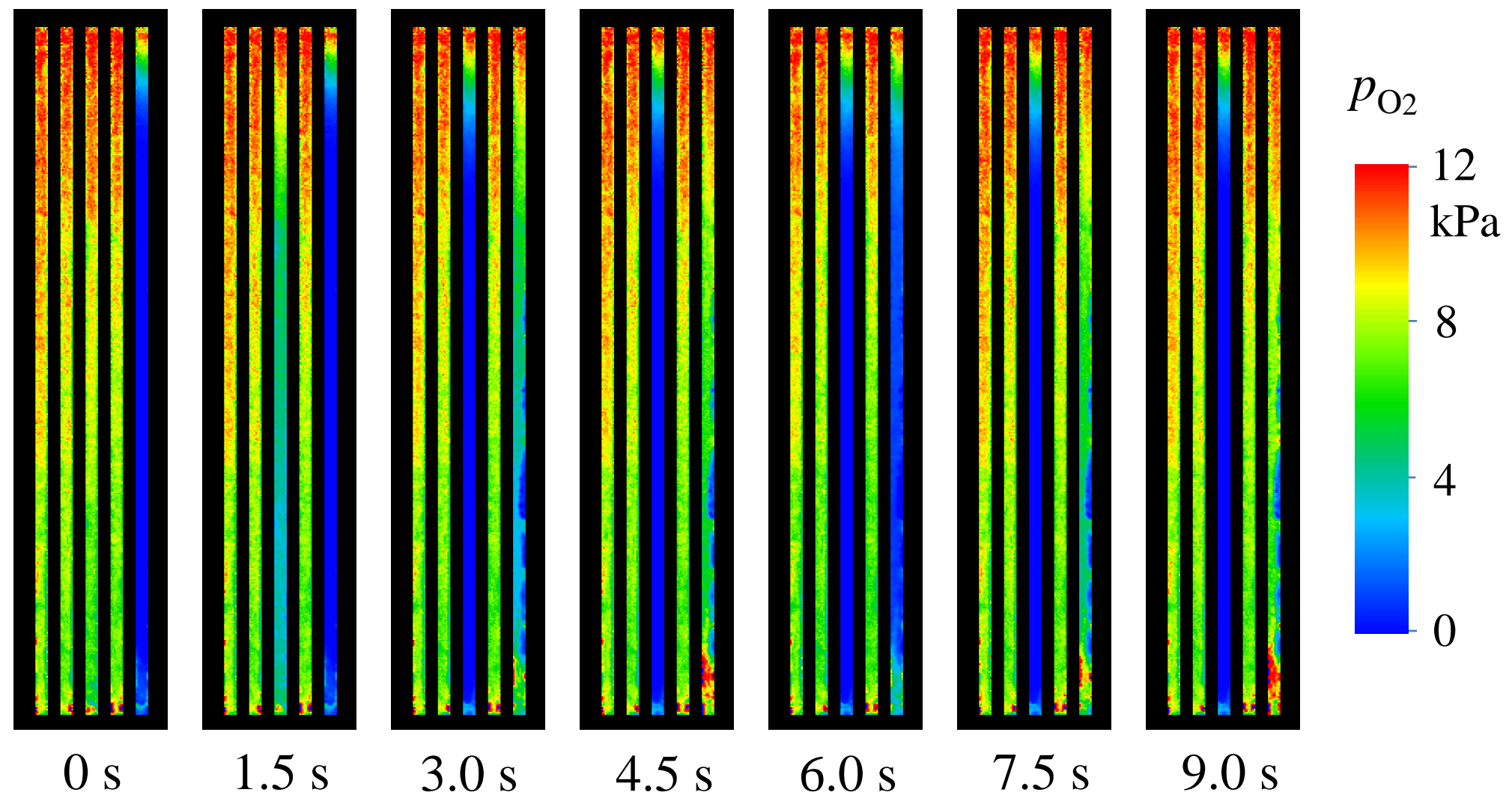




\section{Figure 7}

Nagase et al.

(a)

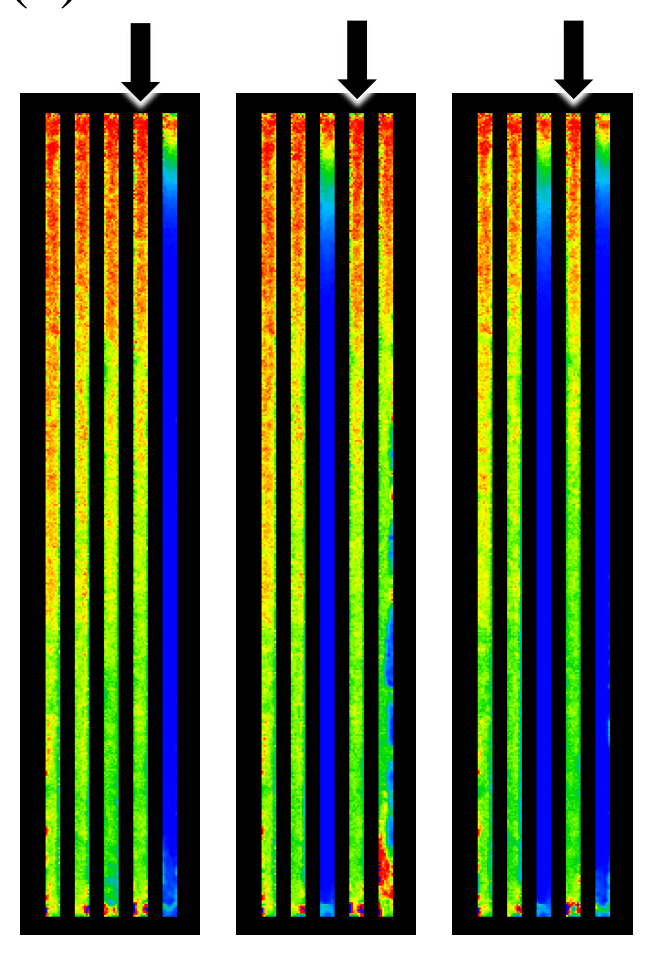

(b)

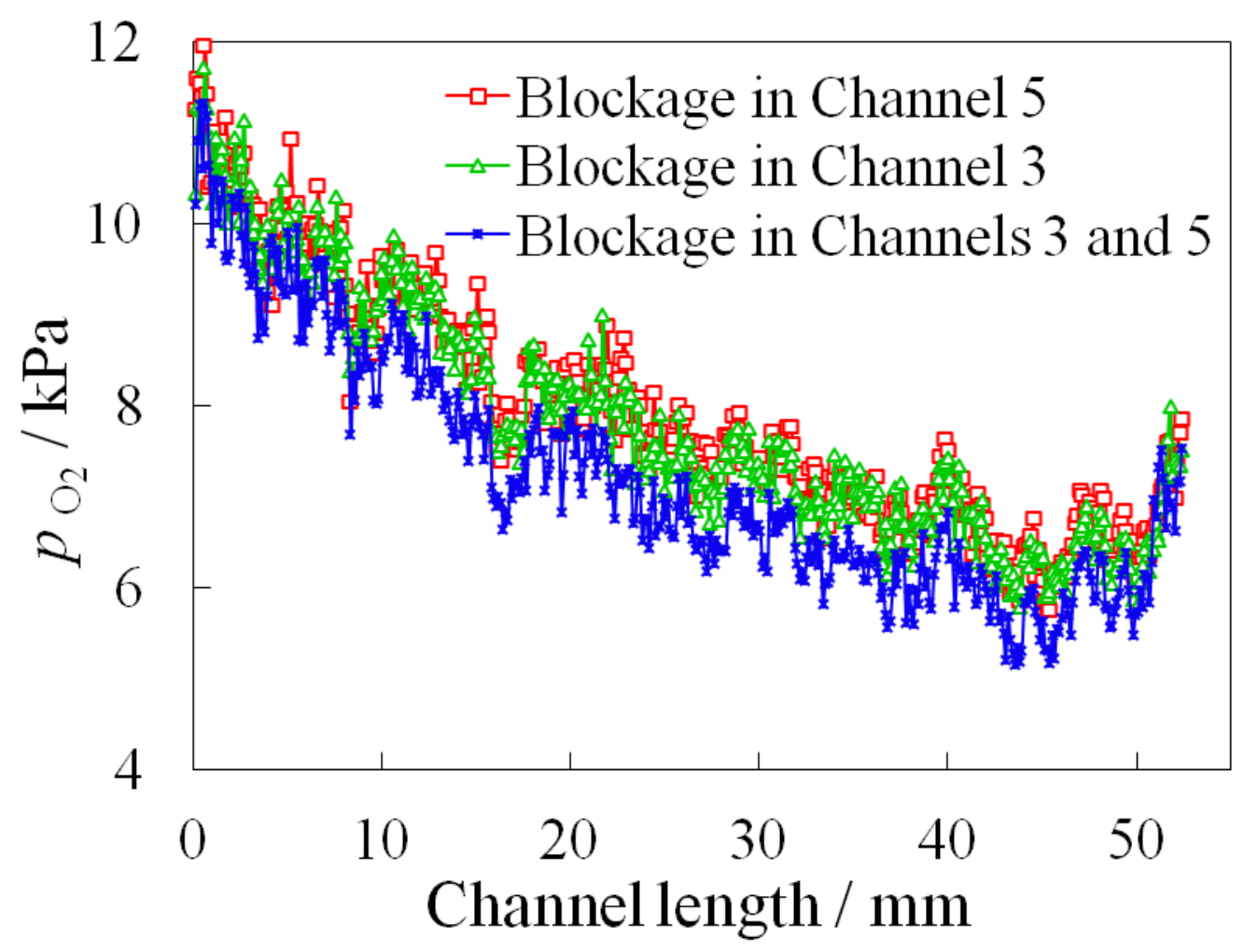




\section{Graphical abstract}

Nagase et al.

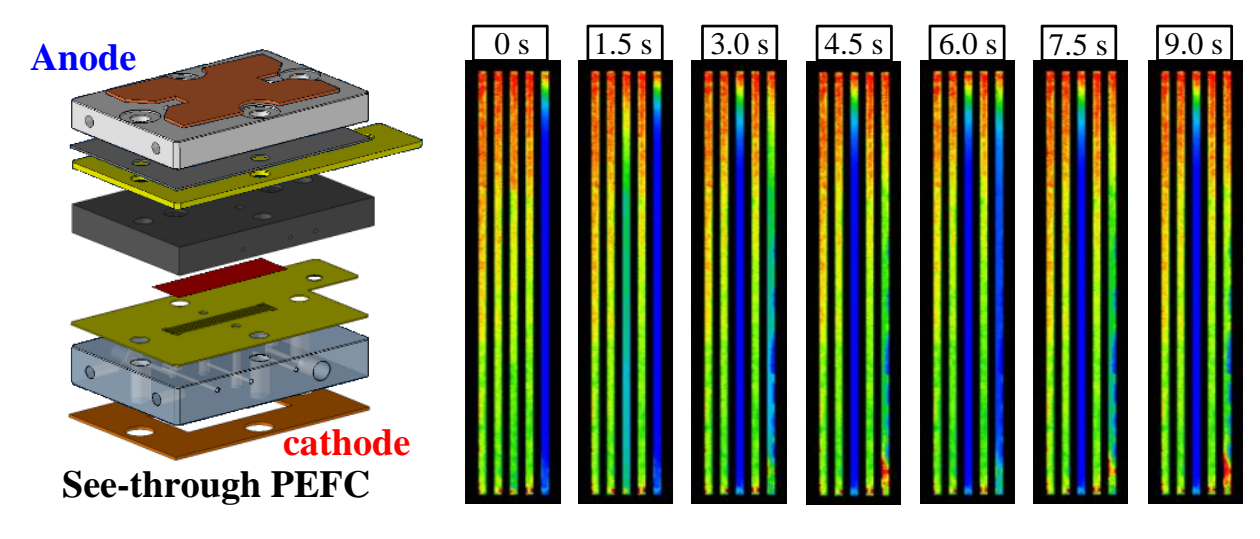

